Volume 3, Number 1, 2017

\title{
Digital Complex for Modeling Processes in Electric Circuits with Protection and Automatic Devices
}

\author{
Oleksandr Ravlyk ${ }^{*}$, Nazar Ravlyk \\ Lviv Polytechnic National University, 12 S. Bandery St., Lviv, 79013, Ukraine
}

Received: February 13, 2017. Revised: March 13, 2017. Accepted: March 21, 2017.

(C) 2017 The Authors. Published by Lviv Polytechnic National University.

\begin{abstract}
The developed digital complex for modeling electromechanical and electromagnetic processes in electric circuits of any configuration with electromagnetic devices, control devices, synchronous and asynchronous motors including their control systems, protection devices and automation, allows us to carry out computation ranging from arc and voltage restoration of switches, to process of starting and restarting of electric motors. Digital Complex is designed for personal computers and computer systems in a Windows environment. Decision modeling tasks were performed by means of design schemes and their parameters created in a graphical environment. To form the majority of schemes of electro technical devices and protection systems a basic set of graphic elements, as well as unilateral and reciprocal links between them is provided. In addition to mutual inductances, models of the controlled dynamic and static connections by management functions developed for modeling electrical machines were used. The authors have developed the new effective methods for forming and solving equations for the significant performance and modeling in real time. The proposed complex is intended for engineering and scientific researches, and can be used for the formation of training systems for students and staff of the electric enterprises.
\end{abstract}

Keywords: digital complex; electromechanical and electromagnetic processes; modeling in real time; nonlinear model of the transformer; nonlinear model of the electric motor.

\section{Introduction}

Modern construction and operation of electro technical devices and protection systems requires physical and, above all digital simulation. This requires the development of the mathematical models and methods for their automatic formation and implementation of digital models using specialized digital complex. Existing digital complexes [1,2], despite their versatility, do not always allow us to create a model with the help of elementary basic elements and require specialized knowledge of programming, which significantly complicates the task of the study. In addition, the versatility of the methods for forming and solving equations of mathematical models of the known digital complexes does not always provide the required performance, not to mention the implementation of real-time models.

Many years of experience of the authors in the field of simulation of electro technical devices $[3,4,5]$, in the improvement of well-known and development of the new more effective methods for the formation [6,7] and solving equations [8] for mathematical models of the electro technical devices and their protection systems allowed us to create specialized digital complex ideas and main characteristics of which are described in this article.

\section{The Digital Complex Purpose and Structure}

The developed complex is intended for operation on PC and compatible devices and allows solving the following problems:

- Analysis of electromagnetic and electromechanical processes in electric circuits of any configuration with electromagnetic and control devices, asynchronous and synchronous machines considering their control systems;

"Corresponding author. Email address: ravlyk.om@gmail.com

This paper should be cited as: O. Ravlyk, N. Ravlyk. Digital Complex for Modeling Processes in Electric Circuits with Protection and Automatic Devices. Energy Eng. Control Syst., 2017, Vol. 3, No. 1, pp. 23 - 28. https://doi.org/10.23939/jeecs2017.01.023 
- Simulation of over-voltages with nonlinear over-voltage limiter and restoring voltages on units of the investigated schemes;

- Simulation of Ferro-resonance processes;

- Simulation of arc processes;

- Simulation of the start and restart electrical motors;

- Optimal parameters definition for tuning automatic regulation systems through electric schemes elements, control algorithms and time constants selection with the aim of achieving necessary quality;

- Simulation of sophisticated control systems considering external factors;

- Simulation of logical schemes;

- Investigation of scheme behavior under the influence of different signals, given both graphically and analytically;

- Parametric and structural optimization of designed devices through multivariate calculations on the basis of matching parameters and units connection scheme solutions being the part of these devices;

- Training systems creation for the investigation of different schemes and processes occurring in them.

The complex is based on the interactive graphic editor and on a powerful digital model. Graphic editor has a user friendly interface and is used for:

- Computed schemes design and their parameters formation on the basis of fundamental elements of the complex and library structures created by users;

- Computed schemes unit design and parameters management;

- Computing of the process management;

- Attaching units for computed coordinates measurement and analysis;

- Formation of electric circuits fragments and separate devices libraries;

- Information input for computation on the digital model;

- Calculation of coordinates, their analysis and print output according to the measurement units attachment;

- Created library elements, database formation.

In fact, the complex is an electrical laboratory with a fundamental elements set and more complicated electric devices created on this base, so user can compile and investigate his own schemes.

Authors tried to combine digital and analog electrical engineering devices, which are now more and more common in power engineering (as frequency converters, switching and regulating) on a single coordinate basis.

\section{The Digital Model Coordinate Basis}

Proceeding from modeling of mutually linked electric on magnetic circuits, the model of the complex is formed on the basis of equations in loop (contour) coordinates - loop currents and magnetic flux linkage (flux), which in the matrix form look as follows [6]:

$$
\begin{aligned}
& B\left|\begin{array}{cc}
L(\bar{i}) & k_{t} \\
k_{t} & -R_{\mu}^{\prime}(\bar{\psi})
\end{array}\right|\left|B_{t}\right| \frac{\partial \bar{i}_{k}}{\partial t} ; \frac{\partial \bar{\psi}_{k}}{\partial t} \mid-B\left(\bar{e}-r \bar{i}-\bar{u}_{c}, 0\right)=0 ; \\
& (\bar{i}, \bar{\psi})=B_{t}\left(\bar{i}_{k}, \bar{\psi}_{k}\right) \\
& C\left(\bar{u}_{c}\right) \frac{\partial \bar{u}_{c}}{\partial t}=\bar{i},
\end{aligned}
$$

where $B$ and $B_{t}$ - direct and transposed matrix of the main loops of mutually linked electric and magnetic circuits; $\bar{i}, \bar{e}, \bar{u}_{c}$ - current, e.m.f. and capacitance voltage vectors for electric circuits; $\bar{\psi}$ - flux linkage vector for magnetic branches of scheme; $r=\operatorname{diag}\left(r_{1}, r_{2}, \ldots, r_{n}\right)$ - diagonal resistance matrix of equivalent scheme's branches; $c=\operatorname{diag}\left(c_{1}, c_{2}, \ldots, c_{n}\right)$ - diagonal matrix scheme's capacitance; $L(i)$ - matrix of own and mutual inductances; $K_{t}$ transformation matrix coefficients; $\bar{R}_{\mu}^{\prime}(\psi)=\operatorname{diag}\left(\bar{R}_{\mu 1}^{\prime}\left(\psi_{1}\right), \bar{R}_{\mu 2}^{\prime}\left(\psi_{2}\right), \ldots, \bar{R}_{\mu m}^{\prime}\left(\psi_{m}\right)\right)$ - diagonal matrix of differential magnetic impedances reduced to one turn, each element of which is defined as $R_{\mu m}^{\prime}=R_{\mu m} / w^{2}$, where $R_{\mu m}$ differential magnetic impedance of a branch; $w$ - number of turns of a winding, to which counted magnetic system. 
For forming and solving equations (1-3), new methods and algorithms were developed. Digital model does not use operations on matrices and vectors. The equations are solved in simple mathematical operations of addition, subtraction, multiplication and division based on the algorithms that use oriented structural numbers [7].

For example, let us show the essence of the method of forming the table connection branches in the loops of arbitrary electrical circuit.

Directed graph corresponds to the electrical circuit connection nodes and branches table $\mathbf{T}_{P}=\left\{\mathbf{T}_{P 1}, \mathbf{T}_{P 2}, \quad, \mathbf{T}_{P q}\right\}$, each oriented structure numbers $\mathbf{T}_{P i}$, which describes the connection of independent vertices (nodes) graph and its edges (branches). For example, $\mathbf{T}_{P 1}=[+1,-2,-4]$ means that the first branch is directed to the first node, the second and the fourth - in the opposite direction.

Put target-based $\mathbf{T}_{P}$ and targeted structural operations on numbers get a table independent loops $\mathbf{T}_{L}=\left\{\mathbf{T}_{L 1}, \mathbf{T}_{L 2}, \quad, \mathbf{T}_{L \mathrm{p}-q}\right\}$, where $\mathbf{T}_{L 1}$ - oriented structure numbers of branches in the first loop with appropriate signs indicating the direction of the branch at the loop, $\mathbf{T}_{L 2}$ - oriented structure of the second loop, etc., $p$ - count the number of branches.

It should be noted that the analytical equations implementation meets system requirements based on the first and - second law of Kirchhoff:

$$
\begin{array}{crl}
\mathbf{A}_{I}\left(\mathbf{T}_{P n}\right)=0, & n=\overline{1, p} ; \\
\mathbf{A}_{U}\left(\mathbf{T}_{L n}\right)=0, & n=\overline{1, p-q .}
\end{array}
$$

Consequently, the appropriate conversion $\mathbf{T}_{P}$ to determine the list of the tree branches $\mathbf{T}_{T}$ size $q$ and list chords $\mathbf{T}_{C}$ size $p-q$.

Logical-mathematical formulas formation of $\mathbf{T}_{T}$ is written as:

$$
\begin{aligned}
& i=\overline{1, q} \text {; } \\
& \mathbf{T}_{T}(i)=0 \text {; } \\
& m=9999 \text {; }
\end{aligned}
$$

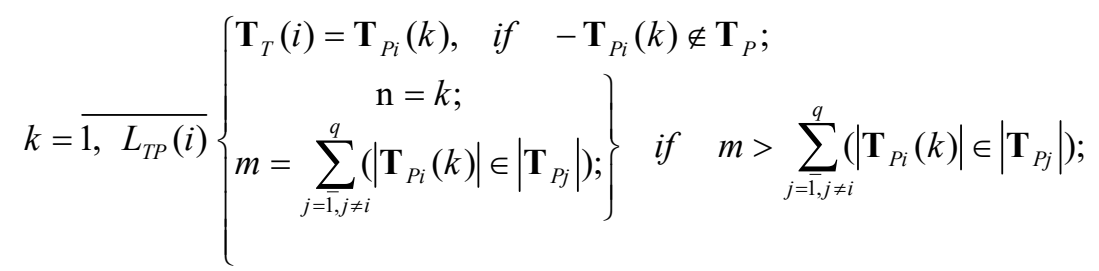

$$
\begin{aligned}
& \mathbf{T}_{P j}=\mathbf{T}_{P j} \oplus \mathbf{T}_{P i}, \quad \text { if } \quad \mathbf{T}_{T}(i)=0 \quad \text { and } \quad \mathbf{T}_{P i}(\mathrm{n}) \in \mathbf{T}_{P j} ; \quad j=\overline{1, q}, j \neq i ; \\
& \mathbf{T}_{T}(i)=\mathbf{T}_{P i}(n), \quad \text { if } \quad \mathbf{T}_{T}(i)=0 \text {, } \\
& \text { and of } \mathbf{T}_{C} \text { : } \\
& \mathrm{s}=0 \text {; } \\
& \left.\begin{array}{c}
\mathrm{s}=s+1, \\
\mathbf{T}_{C}(s)=i,
\end{array}\right\} \quad \text { if } \quad i \notin \mathbf{T}_{T} ; \quad i=\overline{1, p},
\end{aligned}
$$

where $L_{T P}(i)$ - number of component oriented structure numbers.

Based on $\mathbf{T}_{T}, \mathbf{T}_{C}$ and $\mathbf{T}_{P}$ get $\mathbf{T}_{L}$ the following relations:

$$
\begin{aligned}
& i=\overline{1, p-q} ; \\
& \mathbf{T}_{L i}=\mathbf{T}_{C}(i) \oplus \\
& \oplus \begin{cases}\left|\mathbf{T}_{T}(\mathrm{j})\right|, \quad \text { if }-\mathbf{T}_{C}(i) \in \mathbf{T}_{\mathrm{Pj}}, \mathbf{T}_{T}(\mathrm{j})>0 \text { or } \mathbf{T}_{C}(i) \in \mathbf{T}_{\mathrm{Pj}}, \mathbf{T}_{T}(\mathrm{j})<0 ; \\
-\left|\mathbf{T}_{T}(\mathrm{j})\right|, \quad \text { if } \mathbf{T}_{C}(i) \in \mathbf{T}_{\mathrm{Pj}}, \mathbf{T}_{T}(\mathrm{j})>0 \text { or }-\mathbf{T}_{C}(i) \in \mathbf{T}_{\mathrm{Pj}}, \mathbf{T}_{T}(\mathrm{j})<0 ; \quad j=\overline{1, q} .\end{cases}
\end{aligned}
$$


On the basis of the table $\mathbf{T}_{L}$ algorithms for forming own and mutual parameters, electromotive forces of loops and calculation coordinates of loops and of the electric scheme were developed.

For integration of (1-3) equations, a new implicit method of the second-fifth orders is designed and used [8], which provides a stable and fast calculation at significant dispersion of eigenfrequencies and parameters of separate loops of electrical circuit.

For modeling more complicated electric devices (synchronous and asynchronous motors, nonlinear characteristics switch elements, units controlled by voltage or current and changing in time) the digital model is supplemented with elementary basic models (Figure 1) and special algorithms. Regrettably, the description of these algorithms exceeds volume of this paper.

The digital model is based on the list-form forming, optimization and solution algorithms, performing operations of the non-zero elements only, getting into zones of commutation of the key-elements, definition step integration of the equations and other features providing precision needed. Most algorithms have no analogs. Their efficiency is proved by considerable operation speed of digital model.

\section{Realization of Digital Complex}

Original algorithms of drawing, editing, searching, numbering, moving, copying and deleting scheme elements, forming library elements and their parameters were developed by the authors for the realization of the digital complex.
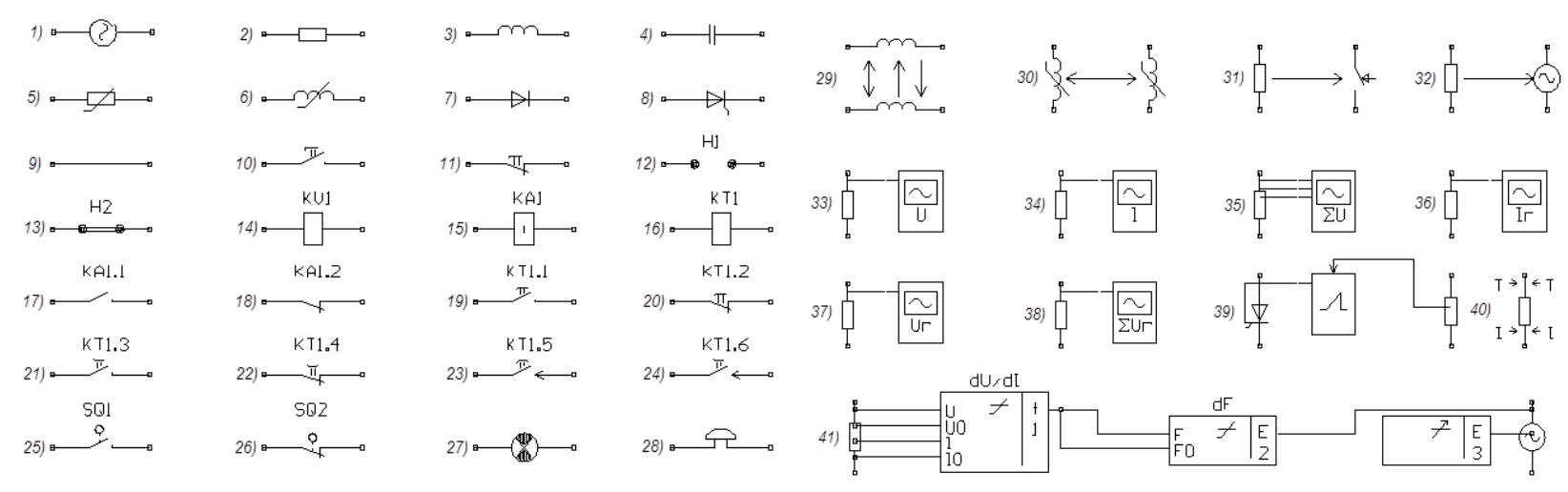

Fig.1. Elementary basic models of the digital complex.

For example, Figure 2 shows simulation of single-phase ground fault three-phase transformer, which is calculated instantly on PC HP Intel(R) Core ${ }^{\mathrm{TM}}$ i5 CPU M520@2.40GHz, and 150 these schemes together - 3 seconds.

Models of the controlled dynamic and static connections (Figure 1, fig.29, 30) by management functions (Figure 1, fig.41) were developed for modeling electrical machines [9].

Simulation start-up of the induction motor power $310 \mathrm{KW} 6.3 \mathrm{kV}$ to the fan load is shown in Figure 3. The calculation takes into account the losses in the steel and saturation, changing the active and inductive resistance of the rotor windings from speed. Model forms equivalent scheme (Figure 3, a). The stator windings are connected to a triangle and are connected to the $6.3 \mathrm{kV}$ electrical networks. The magnetic system is replaced by the three nonlinear inductances (Y-connected) and reduced to the stator windings. The rotor windings are Y-connected. The values of the parameters of the rotor windings are changed from the speed of the rotor.

Electromagnetic connections between the stator windings and magnetic system are constant, between the windings of the rotor and magnetic system - vary the rotational speed of the rotor by means of static and dynamic functions. The mechanical system is modeled by e-l-e-r scheme, where the e.m.f. defined electrical and mechanical torques and the time constant of motion - inductance.

This model allows considering regulation the stator and rotor windings side and the mechanical movement of the addition of appropriate control circuits. The computation time of 50 seconds start-up of the induction motor on a specified above PC is 4 seconds. 


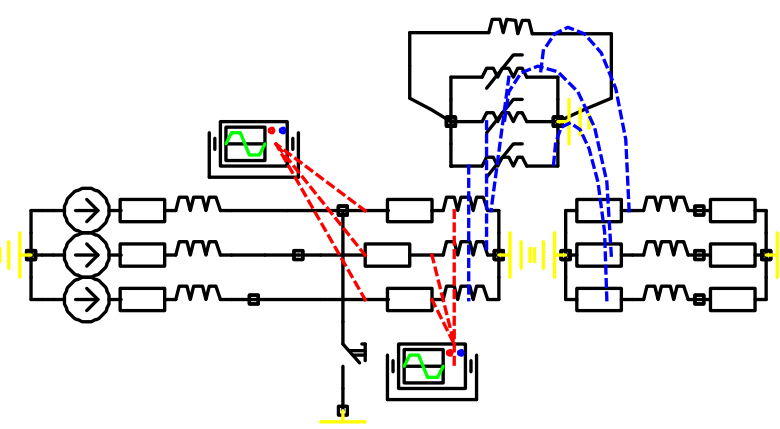

a)

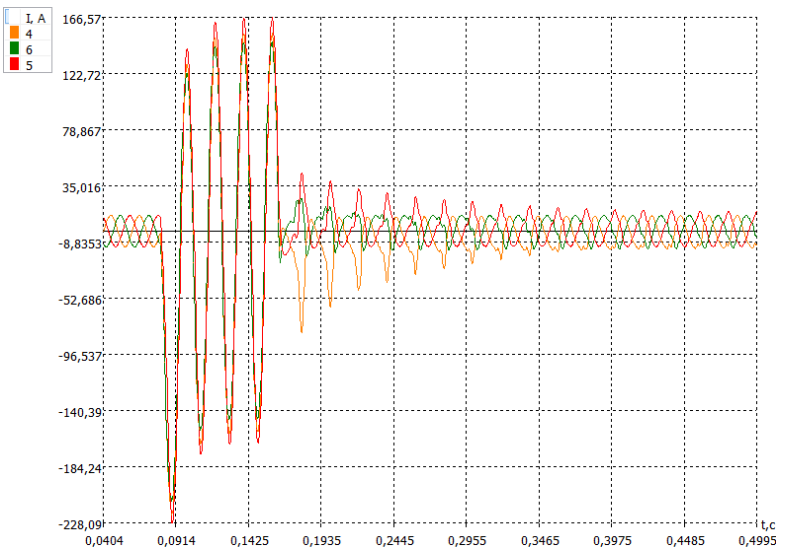

b)

Fig.2. Simulation of single-phase ground fault three-phase transformer: a) equivalent scheme of the nonlinear three-phase transformer; b) currents the primary windings.

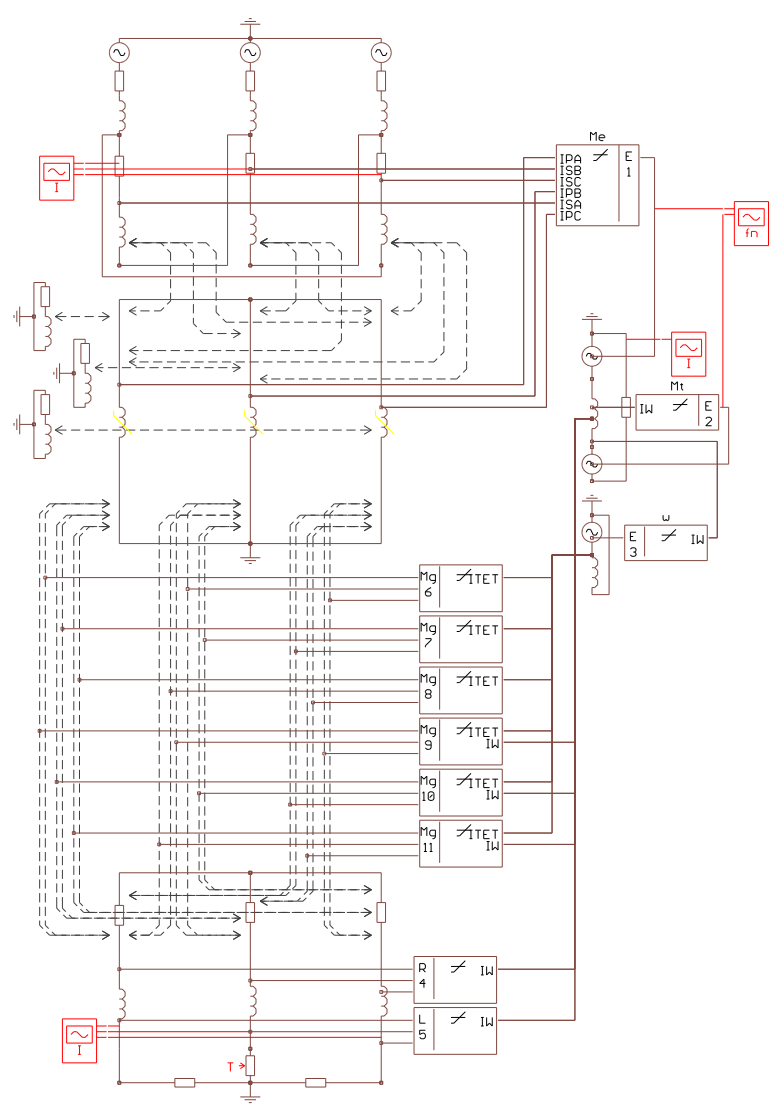

a)

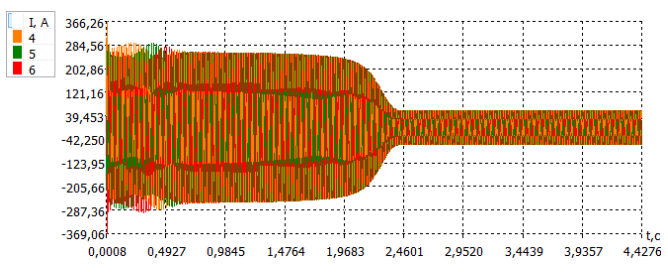

b)

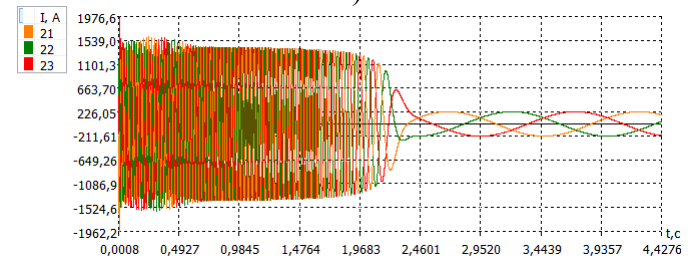

c)

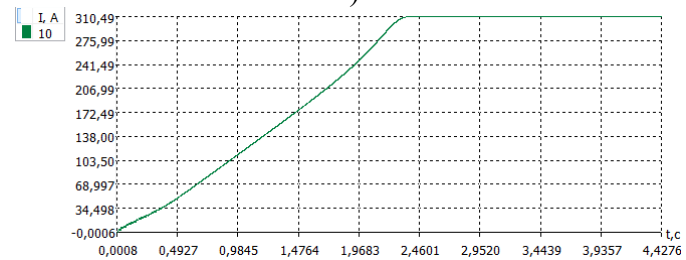

d)

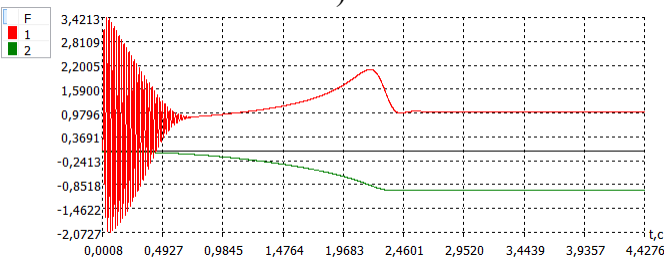

e)

Fig.3. Simulation start-up of the induction motor $310 \mathrm{KW} 6.3 \mathrm{kV}$ to the fan load: a) equivalent scheme; b) currents of the stator; c) currents of the rotor;

d) the rotor speed; e) electrical and mechanical torques on the shaft of the rotor

Many Ukrainian engineering organizations and scientists use this complex for engineering and scientific researches, and it can be used for the formation of training systems for students and electric enterprises staff. 


\title{
5. Conclusion
}

The developed digital complex for modeling electromechanical and electromagnetic processes in the electric circuits of any configuration with electromagnetic devices, control devices, synchronous and asynchronous motors including their control systems, protection devices and automation, allows us to carry out computation ranging from arc and voltage restoration of switches, to process of starting and restarting of electric motors. The new effective methods for forming and solving equations have been developed for significant performance and modeling processes in real time.

\section{References}

[1] Electromagnetic Transient Program (EMTP) Application Guide // EPRI Report No: EL - 4650, Project 2149-1, Westinghouse Electric Corp., Pittsburgh, PA, 1986.

[2] Chernykh Y.V. Modeling of electrical devices in MATLAB. SimPowerSystems. - Piter, 2008. - 288 p. (in Russian)

[3] Ravlyk, O.M., Sabadash, I.O, Grechyn, T.M. Using digital modeling for the development and implementation of microprocessor relay protection and automation. Proceedings of the Institute of electrodynamics. Energy. - 2000. - p. 36 - 41. (in Ukrainian)

[4] Gogolyuk P. T. Grechyn, A. Ravlyk, I. Grinberg. Automated Systems of Scientific Research of Modes and Processes for Power Distribution Systems with Valve Devices and Motor Load. $6^{\text {th }}$ International Conference on Engineering Design and Automation (EDA 2002). - Maui, Hawaii, USA. - 2002. - p. $184-191$.

[5] Segeda, M.S., Ravlyk, O.M., Ravlyk, N.O. Digital model of analysis of electromagnetic processes the electrical network of STC based on implicit one-step methods. Technical electrodynamics. - 2003. - № 4. - p. 65-68. (in Ukrainian)

[6] Ravlyk, O. Comprehensive approach to the mathematical models of elements of electrical networks, protection devices and automation. Scientific Papers of Donetsk National Technical University "Electrical and Power." - 2008. - № 8 (140). - p. 114 - 117. (in Ukrainian)

[7] Ravlyk, O. Formation of state equations that describe processes in electrical networks, systems of protection and automation in contour coordinates. Proceedings of Lviv Polytechnic National University, Electricity and electromechanical systems. - 2008 . - № 615. - p. 116 125. (in Ukrainian)

[8] Ravlyk, O. Methods for solving integral-differential equations finite transients of electrical. Proceedings of Lviv Polytechnic National University, Electricity and electromechanical systems. - 2005. - № 544. - p. 122 - 126. (in Ukrainian)

[9] Ravlyk, O.M. Models of electrical machines to study the processes in electrical networks. Proceedings of Lviv Polytechnic National University, "Electricity and electromechanical systems. - 2009. - № 654. - p. 181 - 191. (in Ukrainian)

\section{Цифровий комплекс для моделювання процесів в електричних мережах, пристроях їх захисту й автоматики}

\author{
Олександр Равлик, Назар Равлик \\ Національний університет «Львівська політехніка», вул. С. Бандери, 12, м. Львів, 79013, Україна
}

\section{Анотація}

Розроблений цифровий комплекс для моделювання електромеханічних і електромагнітних процесів в електричних мережах будь-якої конфігурації з електромагнітними пристроями, пристроями керування, синхронними і асинхронними двигунами, включаючи їх системи управління, пристроїв захисту і автоматики, дозволяє виконувати обчислення процесів в діапазоні від горіння дуги і відновлення напруги вимикачів до процесів пуску і самозапуску електродвигунів. Цифровий комплекс призначений для персональних комп'ютерів і комп'ютерних систем в середовищі Windows. Моделювання здійснюється на основі розрахункових схем і їх параметрів, сформованих в графічному середовищі. Для формування більшості схем електротехнічних пристроїв і систем захисту передбачено базовий набір графічних елементів, а також односторонні і взаємні зв'язки між ними. Крім взаємних індуктивностей використовуються моделі керованих за допомогою функцій управління динамічні і статичні зв'язки, розроблені для моделювання електричних машин. Автори розробили нові ефективні методи формування та рішення рівнянь, що забезпечують значну швидкодію і моделювання в режимі реального часу. Комплекс призначений для інженерних і наукових досліджень, а також для формування систем навчання для студентів і персоналу електричних підприємств.

Ключові слова: цифровий комплекс; електромеханічні і електромагнітні процеси; моделювання в режимі реального часу; нелінійна модель трансформатора; нелінійна модель електродвигуна. 